\section{"QUE EU NÃO MORRA SEM LUTA E SEM GLÓRIA": AS CITAÇÕES DA ILÍADA EM QUÉREAS E CALÍRROE}

\author{
Adriane da Silva Duarte \\ Recebido em: 11/03/2019 \\ Aprovado em: 02/04/2019
}

RESUMO: Quéreas e Calírroe (I d.C.) incorpora um grande número de citações dos poemas homéricos. São cerca de trinta citações diretas, além das referências indiretas, a personagens ou episódios da Ilíada e da Odisseia, com preponderância do primeiro poema. Por isso, o romance de Cáriton oferece um interessante testemunho da recepção da Ilíada no período imperial. Neste artigo, examinarei as citações iliádicas que se aplicam exclusivamente a Quéreas, buscando estabelecer como, e em que medida, elas contribuem para a caracterização do personagem. Constata-se que, associado a diversos personagens do poema, Quéreas adquire uma identidade fluida como herói compósito, o que produz um ruído irônico, derivado do contraste entre o ethos erótico que lhe é próprio e o épico que lhe é agregado.

PALAVRAS-CHAVE: Quéreas e Calírroe; Cáriton; romance antigo; Ilíada; recepção dos clássicos.

\section{"LET ME NOT DIE WITHOUT A STRUGGLE, NEITHER WITHOUT GLORY”: THE QUOTATIONS FROM THE ILIAD IN CHAEREAS AND CALLIRHOE}

\author{
*Professora \\ Associada de Língua \\ e Literatura Grega, \\ Universidade de São \\ Paulo. Bolsista de \\ Produtividade em \\ Pesquisa, CNPq. \\ asduarte@usp.br
}


Chaereas acquires a fluid identity as a composite hero, which produces an ironic note, derived from the contrast between the erotic ethos, which defines him essentially, and an epic one, a new layer added to it.

KEYWORDS: Chaereas and Callirboe; Chariton; Ancient novel; Iliad; Classical reception.

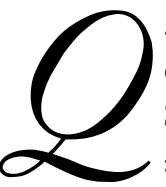

uéreas e Calírroe incorpora um grande número de citações dos poemas homéricos e é sabido que Homero constitui a principal referência intertextual de Cáriton. ${ }^{1}$ São cerca de trinta citações diretas, às quais se somam referências indiretas, a personagens ou episódios da Ilíada e da Odisseia, uma presença bem maior do que a atestada nos demais autores que compõem o cânone dos romances de amor idealizado (ideal love novels). Outra particularidade diz respeito à preponderância da Ilíada sobre a Odisseia, cujo enredo é considerado arquetípico para o gênero romanesco ao associar separação do par amoroso, viagem e provação, retorno e reunião dos amantes ao final. ${ }^{2}$ São quinze citações da Ilíada contra nove da Odisseia - há ainda cinco passagens de caráter formular, que ocorrem em ambos os poemas, algumas em mais de uma ocasião. ${ }^{3}$

Uma das razões para tal reside na relação que a trama do romance estabelece com o enredo da Ilíada. Calírroe, dona de uma beleza arrebatadora e favorecida por Afrodite, assim como o é Helena, é casada com o siracusano Quéreas, que vai à Jônia resgatá-la após seu rapto e venda a Dionísio, seu segundo marido. Assim, o triângulo formado por Quéreas, Calírroe e Dionísio e a oposição entre Grécia e Ásia remetem ao paradigma de Menelau, Helena e Páris e às hostilidades entre gregos e troianos no poema de Homero, embora de forma imperfeita. ${ }^{4}$ A alusão à Ilíada é direta como nas passagens em que Dionísio compara

\footnotetext{
${ }^{1}$ Tilg (2010, p. 141): "One of the most conspicuous features of NAC [Narratives about Callirboe] is the insertion of a large number of lines from the Iliad and the Odyssey. Chariton quotes Homer far more frequently than any other novelist does, about thirty to forty times depending on a definition of a quotation". Reardon (2003, p. 333): “The most frequent of all Chariton's literary references are to Homer".

${ }^{2}$ Cf. Morgan (2008, p. 220): "To greater or lesser degree, and with varying degrees of specificity, all the novels are descants on the second Homeric epic".

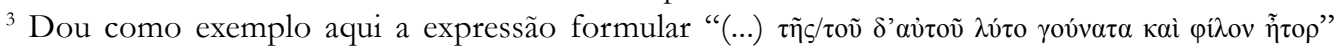
("afrouxaram-se lhe os joelhos e também o caro coração", Iliada, XXI, 114 e 425; Odisseia, IV, 703, XXIII, 205, XXIV, 345), presente em Q\&C [Quéreas e Calírroe], I.1.14; III.6.3, IV.5.9. Para uma análise detida dessa passagem, cf. Duarte (2012).

${ }^{4}$ Paschalis (2013, p. 173-4) atenua a influência da Ilíada em Q\&C com o argumento de que Calírroe não é adúltera como Helena, seu casamento sendo antes fruto da necessidade e até mesmo um sacrifício em prol do filho de que estava gestante; e Dionísio não é visto como Páris, mas antes se equipara a Menelau (Q\&C, II.6; V.2), além do fato de que a disputa pela mulher não resulta em uma guerra. $\mathrm{O}$ autor não considera nem mesmo o destempero de Quéreas como alusivo à raiva de Aquiles. Mas não seria a atenuação devida à idealização no gênero? Scourfield (2003, p. 174) aponta as diferenças entre os heróis de Homero e o de Cáriton, apesar de reconhecer a relação entre eles. Jones (2012, p. 146) descreve Quéreas como uma versão aprimorada de Aquiles (“.... better version of Achilles, an Achilles with benefits”), que reúne as qualidades do guerreiro com a inteligência.
} 
Calírroe a Helena e a si próprio a Menelau (cf. Q\&C, II.6.1 e V.2.7-8). Quéreas e Calírroe também guarda paralelo com a Odisseia, em que o retorno dos protagonistas à Sicília natal e a reunião da heroína ao seu primeiro marido retomam o desfecho do par Odisseu e Penélope, com direito até mesmo a uma cena de reconhecimento. ${ }^{5}$ Dessa maneira, o romance de Cáriton oferece um interessante testemunho da recepção dos poemas homéricos no período imperial.

Em vista da abundância de material, vou me ater ao exame das citações iliádicas que se aplicam exclusivamente a Quéreas, buscando estabelecer como, e se, elas contribuem para a caracterização do personagem. Vou dar especial atenção às menções que o associam a Aquiles, com quem, como apontam diversos autores, ${ }^{6}$ ele comunga algumas características, a começar pela natureza passional, manifesta no temperamento explosivo e no sofrimento extremado diante da perda de um ente querido, que são canalizados para a busca da excelência no campo de batalha. É preciso dizer que, para além de Aquiles, cujas citações são mais abundantes (5/11), Quéreas é equiparado a outros heróis iliádicos, como Pátroclo (2/11), Heitor (2/11) e Diomedes (1/11) - há também uma passagem que, por seu caráter formular, se aplica a várias figuras (1/11, Aquiles entre elas). Além de oferecer um panorama dessas citações, pretendo pensar a recepção da Ilíada no contexto da literatura imperial.

A associação entre Quéreas e Aquiles se dá logo no início do romance, no momento mesmo em que o personagem é introduzido. O narrador compara o jovem a figuras do mito e da história, cuja beleza e excelência são amplamente reconhecidas, a ponto de inspirarem os artistas plásticos (Q\&C, I.1.3): "Quéreas era um rapaz formoso, superior a todos, como os Aquiles, Nireu, Hipólito, Alcibíades que escultores e pintores retratam”.

Em um primeiro momento, a qualidade que sobressai é a beleza, que, contraposta à de Calírroe, que é divina e rivaliza com a de Afrodite, é humana, mas ainda assim capaz de lembrar os mais belos modelos. A comparação, no entanto, tem como função evocar os gêneros que enquadram a narrativa (épica, através de Aquiles e Nireu; tragédia, através de Hipólito; e historiografia, através de Alcibíades) e estabelecer certos traços do caráter do personagem. Segundo De Temmerman (2014, p. 48, tradução minha): “o ponto crucial é que todos os quatro têm mais em comum com Quéreas do que a mera beleza”.

No que concerne especificamente a Aquiles, vale a observação de Scourfield (2003, p. 174, tradução minha), para quem:

\footnotetext{
${ }^{5}$ Cf. Laplace (1980); Morgan (2008); Whitmarsh (2011, p. 55). Chamo especial atenção para o emprego por Cáriton do verso 296, do canto XXIII da Odisseia, que marca a reunião de Odisseu e Penélope após a longa separação, para celebrar o reencontro entre Quéreas e Calírroe (Q\&C, VIII.1.17): “entregaram-

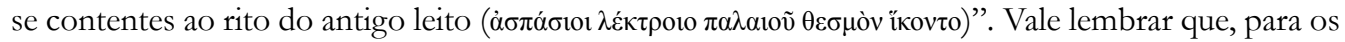
alexandrinos, essa era a marca final de fato do poema. Cf. Loureiro (2013, p. 95).

${ }^{6}$ Hirschberger (2001, p. 169): "Doch der zuerst, Achilleus wird den ganzen Roman hindurch eine wichtige intertextuelle Bezugsfigur für Chaireas bleiben.” Cf. também Scourfield (2003), De Temmerman (2014).
} 
Nenhum leitor antigo teria podido ler o nome de Aquiles sem que seus pensamentos se voltassem, em alguma medida, para a raiva; nenhum leitor atento ficaria surpreso ao encontrar Quéreas se comportando à maneira de Aquiles. ${ }^{7}$

Em comum com Aquiles, Quéreas teria a impulsividade, manifesta no descontrole, nas explosões de raiva e de lágrimas, que não raro resultam no colapso emocional que deixa o personagem à beira do suicídio. Um desses ataques resulta na agressão em que Calírroe é dada como morta e está na origem das desventuras do casal e, por suposto, da trama do romance, assim como o enredo da Ilíada tem início com a ira de Aquiles contra Agamêmnon.

Outro fator de identificação com o herói homérico está na estreita relação que Quéreas mantém com Policarmo, de quem diz o narrador ser "seu melhor amigo, tanto quanto Pátroclo o era de Aquiles em Homero" (Q\&C, I.5.2). A comparação entre Policarmo e Pátroclo e, portanto, entre Quéreas e Aquiles, ocorre num momento em que o herói, julgando ter causado a morte da esposa, pensa em dar fim à própria vida. ${ }^{8}$ É especialmente significativa por circunscrever a raiva de Quéreas à esfera privada, notadamente de natureza erótica, o que à primeira vista pode parecer contrariar o ethos do herói homérico, que, concentrado na preservação de seu nome e reputação, seria avesso às paixões amorosas. No entanto, no recente Achilles in Love. Intertextual Studies, Fantuzzi (2012) passa em revista uma série de testemunhos e versões do mito para mostrar como a figura de Aquiles foi lida em tradições para-homéricas e pós-homéricas como a de um herói apaixonado, protagonista de diversos enredos amorosos, seja com Deidamia, antes mesmo de ir a Troia (e de cuja relação resulta o filho Neoptólemo), seja com Briseida, Pentesileia, Polixena e, claro, Pátroclo, esses já em terras troianas.

A própria Ilíada será lida nessa chave pelos que subscrevem esse retrato do herói, como atestam os escólios. Estou especialmente persuadida de que Cáriton, ao associá-lo a um dos primeiros heróis desse novo gênero centrado na idealização amorosa, pressupõe essa imagem de Aquiles, bastante popular na literatura do império, e que, ao propô-lo como um dos eixos que sustentam a caracterização de Quéreas, não o tenha feito sem uma ponta de ironia. A provocação estaria no fato de empregar matéria cem por cento extraída dos poemas homéricos para traduzir os sentimentos de um herói que se define na e pela paixão erótica - é verdade, contudo, que Quéreas também terá seu momento guerreiro, que discutirei mais adiante. Passemos às citações propriamente ditas.

\footnotetext{
${ }^{7}$ Cf. também Hirschberger (2001, p. 169): "Nicht nur dir Schönheit, sondern die Neigung zum Zorn hat Chaireas mit Achilleus gemeisan".

${ }^{8}$ Também na Ilíada, Aquiles cogita o suicídio ao saber da morte de Pátroclo, ao menos é o que teme Antíloco, que fica ao seu lado e segura suas mãos com receio de que cortasse a garganta com a espada (Ilíada, XVIII, 32-34). Agradeço a Adrian Kelly a lembrança dessa passagem.
} 


\section{Aquiles}

A primeira remissão ao poema homérico relacionada a Quéreas encontra-se igualmente em contexto erótico. Ao saber por um estranho que Calírroe o traía, uma calúnia inventada pelos pretendentes preteridos da jovem, a reação de Quéreas é descrita pelo narrador como a de Aquiles ao receber a notícia da morte de Pátroclo, com citação dos versos 22 a 24 do canto XVIII da Ilíada (Q\&C, I.4.6):

Saiba, então, que sua mulher o está traindo e, para que creia nisso, estou pronto a mostrar o adúltero em flagrante.

Ele assim falou. Negra nuvem de dor envolveu-0, e, tomando com ambas as mãos da terra escura, verteu-a pela cabeça, enfeando o rosto delicado.

O sofrimento do Pelida diante da morte violenta de seu companheiro dileto foi tão devastador que Antíloco temeu que ele atentasse contra a própria vida e "o tenro pescoço com ferro cortasse" (Ilíada, XVIII, 34, na tradução de C. A. Nunes). Parece despropositado o emprego dessa passagem para descrever a reação de Quéreas, já que, por mais dolorosa que seja a suposição do adultério de Calírroe, não seriam fatos da mesma magnitude. De qualquer forma, a escolha da passagem parece apontar para o entendimento do caráter erótico da relação entre Pátroclo e Aquiles, já que indubitavelmente Quéreas sofre de dores de amor. Um contexto termina por "contaminar" o outro, produzindo uma leitura reversa, em que o romance subscreve uma determinada interpretação para o poema épico ao propor a relação entre Aquiles e Pátroclo como equivalente à de Quéreas e Calírroe - apesar da identificação havida entre Policarmo e Quéreas, muitas das citações da Ilíada no romance aplicam-se ao par protagonista.

Homero não explicita qual a natureza do relacionamento entre Aquiles e Pátroclo, mas ao menos desde os Mirmidões, de Ésquilo, está pressuposta uma dimensão erótica. Platão (Simpósio, 179e-180b) e Ésquines (Contra Timarco, 142-150) também o consideram assim, sendo que, para o orador, Homero cala sobre o relacionamento entre Aquiles e Pátroclo porque ele seria evidente para o público culto (pepaideumenois). Morales e Mariscal (2003, p. 293) acreditam que, nessa questão, Cáriton alinha-se com os que viram a relação entre os heróis homéricos como homoerótica.

A mesma passagem da Iliada volta a ocorrer mais adiante no romance, conquanto abreviada, quando Quéreas recebe ordens do sátrapa Mitrídates para ocultar de Calírroe, a quem já não via há muito tempo, sua presença até que chegasse o momento oportuno. Diante da impossibilidade de reunir-se imediatamente à mulher, Quéreas retira-se para seu quarto e (Q\&C, V.2, com citação de Ilíada, XVIII, 23-24)

Atirando-se ao chão e rasgando a roupa, com ambas as mãos tomando verteu-a pela cabeça, enfeando o rosto delicado. da terra escura,

Um pouco adiante, mais uma citação da Ilíada surge no mesmo contexto. Frustrado com o que interpretara como uma reação fria de Calírroe à sua súbita aparição (na verdade, 
a jovem, perplexa com a visão de quem julgava morto, é impedida por Dionísio de reunir-se a ele, $Q \& C$, V.8), Quéreas decide tirar a própria vida e, diante do laço armado, faz um último pedido (Q\&C, V.10.8-9, com citação de Ilíada, XXII, 389-390):

Quando eu morrer, aproxime-se do meu corpo e, se puder, chore. Isso terá mais importância para mim do que a imortalidade. Inclinando-se na minha lápide, diga, mesmo que seu marido e filho bebê estejam assistindo: "Você se vai de verdade agora, Quéreas. Está morto agora. Eu devia tê-lo escolhido no tribunal do Rei!" Eu a escutarei, esposa minha, e talvez até acredite... Fará crescer minha fama entre as divindades debaixo.

Se até mesmo na casa de Hades esquecem-se dos mortos, ainda lá, amada minha, eu vou lembrar-me de ti.

Trata-se de uma passagem interessante em vários aspectos, sendo o primeiro por apresentar uma citação feita pelo próprio personagem. Em geral as citações são atribuídas ao narrador, que desde a frase de abertura do romance apresenta-se como um homem culto, "secretário do orador Atenágoras" ( $Q \& C$, I.1.1), de quem seria de se esperar a familiaridade com o cânone literário. Quéreas voltará a citar a Ilíada em mais duas ocasiões, o que reforça a sua identificação com o poema e contribui para caracterizá-lo também como detentor de uma educação formal, pouco enfatizada anteriormente.

Um segundo elemento de interesse está no fato de os versos iliádicos estarem levemente modificados (o que também se repetirá). A alteração é mínima, visando apenas uma adaptação de gênero. Em vez de empregar o masculino pí̉ov $\mu \varepsilon \mu v \eta \dot{\sigma o \mu}$ ' $\dot{\tau} \tau$ aípov,

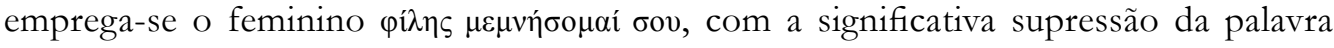
hetairos, companheiro, substituída pelo pronome pessoal de $2^{a}$ pessoa. Obviamente, hetairos é uma palavra que assume sentidos diversos conforme o gênero em que é empregada. No masculino define a camaradagem de companheiros de armas, notadamente nos poemas épicos; no feminino, onde este sentido também se atesta (cf. p. ex. Ilíada, IX, 2, em que a Fuga é dita companheira do Pânico, e Ilíada, IV, 441, em que Éris é companheira e irmã de Ares; note-se que nesses casos refere-se a personificações), é mais frequentemente aplicado para indicar a cortesã, hetaira, acepção que se quis explicitamente evitar nesse contexto, mas que poderia ser ativada pelos leitores que fossem capazes de remontar o texto original - a situação é bastante complexa, especialmente se tendo em vista a assimilação de Calírroe a Helena, que não raro é (auto)designada por termos de caráter ainda mais pejorativo. ${ }^{9}$ Nesse

\footnotetext{
${ }^{9}$ Sobre o tratamento ambíguo conferido por Cáriton a essa aproximação entre Helena e Calírroe, cf. De Temmerman (2014, p. 52-3). Nessa mesma chave, é de grande relevância para a compreensão da personagem de Cáriton a composição da persona de Cíntia como Helena nas elegias de Propércio. Cf. Martins (2017, p. 163): "A Cíntia de Propércio tem como um de seus modelos construtivos a Helena de Troia, seja como modelo de $\tilde{\eta} \theta 0 \varsigma$ - mítico, portanto -, seja como modelo de discurso perfeito logo pictórico". No caráter é a junção de beleza e infidelidade; no retórico, torna-se metáfora para a poesia elegíaca, ou seja, para o gênero que se pratica.
} 
último caso, também se pode pressupor um uso irônico de Homero (o relevante não é o que se fala, mas o que se cala).

Os versos homéricos mais uma vez se referem ao relacionamento entre Aquiles e Pátroclo, em que o Peleida, após matar Heitor, lembra-se de que seu companheiro jaz insepulto e declara que jamais se esquecerá dele, nem enquanto viver, nem mesmo depois de morto, já no Hades. Essa mesma determinação, que vai se tornar um topos literário, “o amor além da morte", exprime Quéreas com relação a Calírroe.

O topos do amor além da morte será caro aos elegíacos e, especialmente, a Propércio. Na elegia I.19, o eu-lírico fantasia sobre sua morte, expressando o temor de que Cíntia falte ao seu funeral (cf. v. 3-4: "que o teu Amor não venha ao meu enterro - / eis um medo maior que o das exéquias"; v. 21: "Eu temo que desprezes o meu sepulcro, Cíntia”) e assegurando que seguirá amando-a (v. 11-12: “Lá, seja como for, eu cantarei teu rosto:/ cruza as margens do Fado um grande Amor”, traduções de Guilherme Gontijo Flores). É notório aqui o tratamento irônico que recebe a relação amorosa no gênero, que se expressa inclusive no transbordamento emotivo e na "idealização" da amada. Parece que Cáriton aqui promove uma sobreposição entre gêneros, produzindo um deslocamento da citação épica num contexto que sugere o elegíaco - aliás, a referência ao gênero épico, sabe-se bem, é corrente em Propércio, como forma de delimitar e valorizar sua própria prática poética. ${ }^{10}$

As duas últimas ocorrências situam-se em contexto bélico. Acreditando ter perdido Calírroe para sempre, Quéreas une-se aos egípcios revoltosos contra o Rei Persa, a quem ele atribui seu revés. É um momento de inflexão da personagem, que em certa medida parece se libertar da paixão redutora e assume uma atitude compatível com seu status social, o que marca para alguns o amadurecimento do herói e seu ingresso na vida adulta, demonstrado na capacidade de autocontrole. ${ }^{11} \mathrm{O}$ herói da elegia dá lugar ao da epopeia.

Naquele que é o seu maior feito militar, a captura da cidade de Tiro, Quéreas será mais uma vez comparado a Aquiles, que, como ele, busca se vingar daquele que o separara de seu caro Pátroclo (Q\&C, VII.4.3; Ilíada, XIII, 131 e XVI, 215; XXI, 20):

Em formação cerrada, Quéreas conduziu-os contra Tiro, de modo a aparentarem estar em menor número. E, de fato, era

escudo escorado em escudo, capacete em capacete, homem em homem.

$* * *$

Um dos tírios transmitiu essa mensagem aos de dentro e, abrindo os portões, o general saiu na companhia de uns poucos homens. Quéreas matou-o primeiro e lançou-se contra os demais, golpeava por todos os lados, e deles partia gemido indigno.

Um trucidava outro, como leões que atacam um rebanho bovino desprotegido.

\footnotetext{
${ }^{10}$ Cf. Martins (2017, p. 164), para quem Propércio se vale da matéria épica de forma seletiva e sempre de modo a conformá-la às necessidades da elegia.

${ }^{11}$ Cf. Jones (2012, p. 146-7) para discussão da andreia de Quéreas relacionada a paideia e phronesis.
} 
O primeiro verso ocorre duas vezes na Ilíada para descrever os gregos postos em formação para enfrentar os troianos. Na segunda destas, no canto XVI, segue-se à exortação de Aquiles aos mirmídones para que combatam sob a liderança de Pátroclo, embora ele mesmo ainda se mantenha à parte. O segundo verso, já com o herói reintegrado à batalha, pertence à investida de Aquiles contra os troianos, que, para escapar de sua perseguição, haviam se lançado ao rio. Cáriton reforça a dicção épica da passagem com uso de um símile, que, se não tem correspondência exata com os homéricos, os evoca com toda clareza: "um trucidava outro, como leões que atacam um rebanho bovino desprotegido". A comparação de situações de combate acirrado ao ataque de leões sobre o gado é relativamente recorrente na Ilíada, e o próprio Aquiles será comparado ao animal em pelo menos duas ocasiões (Ilíada, XX, 164-175; XXIV, 41-45). ${ }^{12}$

A segunda menção é especialmente curiosa já que tanto o verso citado quanto o símile também se acham na Odisseia (XXII, 308; 401-406), onde estão relacionados ao massacre dos pretendentes por Odisseu, um contexto bastante significativo, uma vez que Quéreas pretendia atingir seus rivais no amor por Calírroe, Artaxerxes e Dionísio, que lutava junto ao Rei, capturando cidades aliadas.

Isso sugere que Cáriton quis atribuir a Quéreas, no momento de sua aristeia, características tanto de Aquiles quanto de Odisseu, heróis que, na medida em que representam paradigmas distintos, são tidos por incompatíveis. No entanto, Quéreas alia, de fato, a bravura e o combate aberto de Aquiles à astúcia odisseica - para vencer a resistência dos tírios, entrincheirados atrás das muralhas, ele se faz passar por um desertor das tropas egípcias e, assim que os portões da cidade são abertos, ordena o ataque. Essa sobreposição dos heróis homéricos também implica, indiretamente, a aproximação de Quéreas com Eneias, que é um herói híbrido, muito embora rejeite a métis de Odisseu, valendo lembrar que a Eneida, cujo herói também deve a ambos os paradigmas homéricos, é, do mesmo modo, um importante subtexto em Cáriton.

\section{DiOMEdEs E HeIToR}

No mesmo contexto marcial, somam-se às referências a Aquiles duas citações que aproximam Quéreas de outros dois heróis iliádicos, Diomedes e Heitor. Ao se apresentar ao faraó, Quéreas faz o mais incisivo discurso da sua guinada (vale lembrar que a competência retórica é também parte dessa mudança), que tem por fecho as palavras proferidas por Heitor antes do enfrentamento com Aquiles (Q\&C, VII.2.4; Iliada, XXII, 304-305):

Artaxerxes impôs-nos sua tirania (...). Trazemos a nós mesmos e colocamonos a seu dispor como leais aliados, tendo dois estímulos para a coragem: desejo de morte e de vingança. Já me havia dado por morto em vista de tudo que passei, mas continuo vivo apenas para castigar o inimigo.

\footnotetext{
${ }^{12}$ Para outras ocorrências, cf. Ilíada, V, 161-164; XI, 170-178; XV, 630-640; XVI, 487-491; XVII, 540-542.
} 


\section{Que eu não morra sem luta e sem glória, mas após algo grandioso, para que de mim saibam os vindouros!}

Vários tópicos característicos da identidade grega surgem em sua breve fala: o repúdio à tirania, especialmente à bárbara (é certo que ele se alia aos egípcios, que, mesmo após a helenização decorrente das conquistas de Alexandre, ainda não entendem o grego - é preciso um intérprete para se fazer compreender, ao menos pelo grosso do exército) e, sobretudo, a busca da glória baseada na coragem (andreia). Merece especial destaque a formulação "desejo

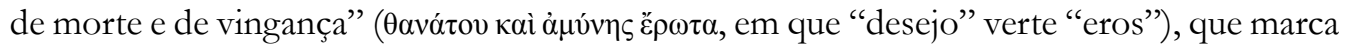
a ressignificação do termo eros da instância amorosa para a marcial.

A referência a Heitor, novamente uma escolha atribuída ao personagem e não ao narrador, também é reveladora da sua paideia e certamente contribui para a compreensão das intenções do jovem. O desejo de morte diz respeito não apenas ao inimigo, mas a si próprio, já que, na Ilíada, Heitor tem consciência de que o combate com Aquiles vai lhe custar a vida. Quéreas, que, como visto, inúmeras vezes cogita o suicídio ao longo do romance, havia sido convencido por Policarmo a associar o desejo de morte à vingança, de modo a "deixar para as próximas gerações a história célebre de dois gregos que, tratados injustamente, castigaram por sua vez o Grande Rei e morreram como homens" (Q\&C, VII.1.8). A citação, portanto, não deixa de ser irônica, na medida em que revela que Quéreas ainda se vê como herói romântico, usando a guerra apenas como trampolim para realizar seu desejo de morte, consequência de sua separação de Calírroe.

Em passagem anterior do romance, Quéreas já havia sido equiparado a Heitor. Trata-se de uma citação do mesmo canto XXII (Q\&C, III.5.6; Ilíada, XXII, 82-83), em que Hécuba tenta demover o filho de enfrentar Aquiles, desnudando os seios:

Filho, venere estes seios e tenha piedade de mim, se alguma vez, lhe dei o peito confortador!

No momento em que Quéreas já estava embarcado para seguir em missão de resgate a Calírroe na Jônia, seus pais imploram para que não os abandone em sua velhice. Sensibilizado pela súplica extremada da mãe, o jovem atira-se ao mar para escapar "à escolha excludente: ou abandonar a busca por Calírroe ou afligir seus pais" ( $Q \& C$, III.5), sendo preciso que os tripulantes se lancem atrás dele para salvá-lo e Hermócrates disperse a multidão reunida no porto e ordene a partida da trirreme. ${ }^{13}$ Trata-se de uma eloquente manifestação da falta de sōphrosynè que caracteriza o personagem, antes de sua decisão de provar seu valor com atos de bravura. Para De Temmermann (2014, p. 91, tradução minha), a retomada da máscara de Heitor, no momento em que antecede sua morte, visa a enfatizar a mudança pela qual ele passa:

\footnotetext{
${ }^{13}$ A citação aqui está mais uma vez a cargo de uma personagem, o que coloca em questão em que medida a mãe de Quéreas teria citado Homero conscientemente ou não. Essa discussão terá que ser feita em outra oportunidade, mas para o argumento de que outro personagem feminino, Calírroe, gasta seu Homero com pertinência e cálculo, cf. De Temmerman (2014, p. 52).
} 
Seu desejo de morrer não mudou, mas agora ele o adapta em função de um objetivo maior (infligir dano a seu inimigo, Artaxerxes). O desejo de Quéreas de morrer permanece a base da sua conduta. Mas, à diferença de antes, ele agora é capaz de canalizá-lo de um jeito 'sōphrōn'.

Para fechar as referências à Ilíada em contexto bélico, há uma passagem, novamente do livro VII de $Q \& C$, em que Quéreas adapta o discurso com que Diomedes rechaça a sugestão de Agamêmnon para que os gregos abandonem Troia (Q\&C, VII.3.5; Ilíada, IX, 48-49):

Mas se sua vontade é outra, deixe comigo os que ficarem voluntariamente, nós dois, eu e Policarmo, combateremos,

...pois com os deuses viemos.

Diante da intenção do faraó de recuar para Pelúsio sem investir contra Tiro, Quéreas manifesta sua determinação de capturar a cidade, nem que seja apenas em companhia de Policarmo, nome que ele substitui a Estênelo, escudeiro do Tidida. A citação, mais uma vez, evidencia o conhecimento de Quéreas da Ilíada e sua busca por modelos heroicos. A escolha de Diomedes é menos óbvia do que as dos demais heróis, mas não deve passar despercebida sua deliberada disputa com Afrodite no canto V (Ilíada, V, 311-354) - nessa passagem também se apresenta Estênelo, a secundar o herói em perseguição à deusa (cf. De Temmerman, 2014, p. 94). Em passagem posterior, Quéreas vai designar-se ironicamente

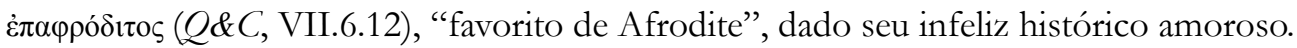

\section{Pátroclo}

Falta examinar as citações em que Quéreas é identificado com Pátroclo, sempre em contexto amoroso. A primeira ocorre no momento em que Calírroe, que se descobrira grávida de Quéreas, tem que tomar a difícil decisão de abortar a criança ou de desposar Dionísio de modo a atribuir-lhe a paternidade, preservando a vida do filho. Depois de passar insone boa parte da noite examinando a questão, ela adormece e vê o marido em sonhos $(Q \& C$, II.9.6; Ilíada, XXIII, 66-67):

\section{Postou-se diante dela uma imagem de Quéreas, semelhante em tudo a ele, no porte, nos belos olhos e na voz, trajava ainda idênticas vestes ao redor do corpo.}

Quéreas aparece a Calírroe como o espectro de Pátroclo diante de Aquiles para pedir-lhe que não o deixe sem sepultura.

O mesmo contexto recorre no livro IV, quando, fracassada a missão de resgate comandada por Quéreas, Calírroe já o acredita morto, entregando-se ao desespero. Dionísio tenta reanimá-la, sugerindo que cumpra os ritos fúnebres devidos ao primeiro marido, na esperança de que possa depois esquecê-lo e dedicar-se à nova família. Para tal, ele se dirige a 
ela da mesma forma que Pátroclo a Aquiles na passagem comentada anteriormente, citando um verso contíguo (Q\&C, IV.1.3; Ilíada, XXIII, 71):

Levante-se, querida, e trate de providenciar um túmulo para o infeliz! Por que você perde tempo com coisas impossíveis e negligencia as suas obrigações? Imagine que ele está de pé a sua frente e diz:

Enterre-me, para eu transpor o quanto antes as portas do Hades.

Nos dois trechos, Quéreas é equiparado a Pátroclo morto e, consequentemente, Calírroe é posta no lugar de Aquiles, retomando com papéis trocados a correlação estabelecida previamente, mas sem alterar o principal, o fato de que a relação entre os heróis homéricos é paradigmática para tratar daquela que têm Quéreas e Calírroe. ${ }^{14}$ Ambos os casos parecem reforçar a passividade de Quéreas. Para De Temmerman (2014, p. 57-8), a assimilação de Quéreas ao espectro de Pátroclo, em passagens em que embasa a decisão da heroína de celebrar novo casamento e a incentiva a seguir a vida sem ele, "contribui para a construção do status transgressivo de Calírroe como mulher de dois homens”, reforçando o paradigma de Helena.

\section{CoNClusões: IDENTIDADES FLUIDAS, POROSIDADE ENTRE GÊNEROS}

Meu tratamento das citações da Ilíada por Cáriton pressupõe a intenção de ativar nos leitores do romance o contexto das passagens citadas, promovendo, assim, uma relação intertextual de fato, que impacta, inclusive, a recepção do poema homérico. Há, no entanto, outra hipótese possível, a de que Cáriton, que se apresenta como secretário de um rétor, fizesse um uso mais mecânico dos poemas homéricos, citando-os a partir de coletâneas dos trechos mais populares, selecionadas para fins retóricos. É o que pensa Miralles (2014, p. 157), que, ao analisar uma passagem sobre a qual também nos debruçamos aqui ( $Q \& C$, V.2.4), conclui que a inadequação entre os contextos da citação iliádica e do romance sugere que não houvesse o propósito de remeter ao texto de origem, mas "a uns versos soltos que, porque são homéricos, podem contribuir de forma eficiente para caracterizar de forma hiperbólica a aflição de Quéreas em um momento culminante da narrativa". Para ele (2014, p. 158-9, tradução minha)

O texto de que se vale Cáriton naquele ponto parece ter sido selecionado previamente, como material de sua escrita (...), parece tê-lo achado já extraído em alguma parte, já estar codificado, repertoriado, como exemplo de expressão prestigiosa da aflição mais extrema. A sua aparenta ser a memória de um texto já escolhido e catalogado.

\footnotetext{
${ }^{14}$ Dalzell (apud Martins, 2017, p. 174) sugere que Propércio, em sua elegia 4.7, relê essa mesma passagem da Ilíada ao imaginar a visita que o eu-lírico recebe de Cíntia recém-falecida. Ou seja, talvez, mais uma vez a matéria épica esteja contaminada pelo viés elegíaco em Cáriton.
} 
Assim, ao compor seu discurso, escritor ou orador poderiam consultar e escolher o trecho mais conveniente ao seu argumento em antologias já preparadas para esse fim, à maneira de um dicionário de citações. $\mathrm{O}$ uso de versos relativos a personagens diferentes para caracterizar Quéreas parece indicar que seja esse o caso na medida em que a ênfase recairia nas passagens propriamente ditas, exemplares de certas situações ou virtudes, como coragem ou dor, muitas delas extraídas de momentos climáticos dos poemas (estou pensando especialmente nas citações dos cantos IX, XVII e XXII da Ilíada, analisadas aqui, mas também em Odisseia XXII e XXIII), que são certamente muito conhecidos e, portanto, elegíveis para essas seletas.

Pode-se argumentar, por outro lado, que é justamente a celebridade das citações que tornaria quase improvável que a correlação entre os textos passasse despercebida ao leitor. Afinal, é difícil imaginar que um público capaz de reconhecer a dicção homérica ignorasselhes o contexto, as palavras de Aquiles ao receber a notícia da morte de Pátroclo ou as de Heitor quando caminhava em direção ao Peleida. E o próprio Miralles, como visto acima, afirma que o efeito buscado é mais efetivo na medida em que a assinatura homérica sobressai.

Nesse caso, há de se pensar que os versos homéricos foram usados intencionalmente para a caracterização dos personagens. O caso de Quéreas, acima examinado, é dos mais interessantes, na medida em que se verifica, desde a apresentação que faz da personagem o narrador, a construção de uma identidade fluida, em que o leitor é convidado a associar o herói do romance a diversas figuras oriundas da literatura e da história, que se somam em camadas. Considerado somente o contexto iliádico, ele é vinculado a Aquiles, Nireu, Pátroclo, Heitor e Diomedes. Isso faz de Quéreas um herói compósito, conferindo-lhe uma espécie de estatuto sumular, ao mesmo tempo em que se produz um ruído irônico, derivado do contraste entre o ethos erótico, e (por que não?) elegíaco, e épico (agregado) do personagem - ou seja, o leitor é desafiado a pensar as atitudes de Quéreas à luz do código heroico, por exemplo. Para De Temmerman (2014, p. 93, tradução minha)

A técnica adotada pode ser descrita como "duplamente metafórica": o personagem é descrito a partir da associação (intertextual) de Quéreas com Aquiles e Heitor e, ao mesmo tempo, essas associações (intratextuais) evocam, e invertem, instâncias anteriores do mesmo paradigma.

De um ponto de vista macroestrutural, as frequentes citações de Homero no romance têm por efeito reforçar a imagem do narrador/Cáriton como um erudito, conhecedor do cânone, qualidade que ele deve, ao menos em parte, ter em comum com seus leitores, além de contribuir para a ornamentação do texto, elevando sua elocução. Com isso, enfatiza-se a associação entre esse gênero então recente, o do romance (do qual, não podemos nos esquecer, Cáriton é um dos primeiros expoentes), com o da épica e, através dela, com a grande tradição da poesia grega. Pode-se afirmar, assim, que o conjunto das citações presentes no texto contribui para sedimentar a autoridade do autor, bem como elevar o estatuto de sua obra junto aos leitores. $\mathrm{O}$ jogo intertextual põe à prova a erudição do leitor, que se compraz 
no reconhecimento de cada citação - os jogos eruditos, como se sabe, são herança de uma estética helenística que sustenta a literatura feita no período imperial.

Como visto, é provável que haja mais de um propósito para o emprego do texto de Homero por Cáriton: como ornamento, como meio de conferir autoridade ao texto e como elemento auxiliar na composição dos personagens e da cena. Por não serem excludentes, nada impede que todos esses fatores estejam conjugados. No entanto, uma coisa é certa, independentemente da intenção do autor (e esse é sempre um terreno pantanoso, o da intenção, e, no limite, irrelevante): a interpretação dessas passagens competirá sempre aos leitores, aos de então (de cuja resposta não temos pistas) e aos de hoje. Em vista disso, defendo que o romance de Cáriton constitua uma das mais originais recepções do poema de Homero.

\section{ReferênCIAS}

CÁRITON. Quéreas e Calírroe. Tradução e apresentação Adriane da Silva Duarte. São Paulo: Editora 34. No prelo.

CHARITON. De Callirhoe narrationes amatoriae Chariton Aphrodisiensis. Edição de Bryan P. Reardon. Monacchi: K. G. Saur, 2004.

DALZELL, A. Homeric themes in Propertius. Hermathena. Trinity College Dublin Review, n. 129, p. 29-36, 1980.

De TEMMERMAN, Koen. Crafting characters. Heroes and heroines in the ancient Greek novel. Oxford: Oxford University Press, 2014.

DUARTE, Adriane da Silva. Afrouxaram-se os joelhos e o caro coração, uma fórmula homérica e seu emprego por Cáriton. Letras Clássicas, v. 16, p. 3-17, 2012.

FANTUZZI, Marco. Achilles in love. Intertextual studies. Oxford/New York: Oxford University Press, 2012.

FUSILLO, Massimo. Il testo nel texto. La citazione nel romanzo greco. Materiali e discussioni per l' analisi dei testi classici, v. 25 (Studi sul romanzo antico), p. 27-48, 1990.

HIRSCHBERGER, Martina. Epos und Tragödie in Charitons Kallirhoe. Ein Beitrag zur Intertextualität des griechischen Romans. Würz̧burger Jahrbücher für die Altertumswissenschaft, v. 25, p. 157-86, 2001.

JONES, Meriel. Playing the man. Performing masculinities in the ancient Greek novel. Oxford: Oxford University Press, 2012.

LAPLACE, Marcelle. Les legendes troyennes dans le roman de Chariton Chairéas et Callirhoé. Revue des Études Grecques, v. 93, p. 83-125, 1980.

LOUREIRO, João Diogo R. P. G. Os finais da Odisseia. A autenticidade do canto XXIV. Boletim de Estudos Clássicos, Coimbra, v. 58, p. 95-117, 2013. Disponível em: http://dx.doi.org/10.14195/0872-2110_58_6. Acesso em: 24 ago. 2018. 
MANUWALD, Gesine. Zitate als Mittels der Erzählen. Zur Darstellungstechnik Charitons in seinen Roman Challirboe. Würz̧burger Jachbücher fur die Altertumwissenchaft, v. 24, p. 97-122, 2000 .

MARTINS, Paulo. Tum longas condimus Iliadas. A Helena de Propércio. Archai, n. 21, p. 159206, 2017.

MIRALLES, Carles. Memòria i ús dels textos. In: MESTRE, Francesca; GÓMEZ, Pilar. (Ed.). Three centuries of Greek culture under the Roman empire. Barcelona: Publicacions i edicions de la Universitat de Barcelona, 2014, p. 155-64.

MORALES, Manuel Sanz; MARISCAL, Gabriel Laguna. The relationship between Achilles and Patroclus according to Chariton of Afrodisias. The Classical Quarterly, v. 53, n. 1, p. 292-5, 2003.

MORGAN, John. Intertextuality. 1. The Greek novel. In: WHITMARSH, Tim (Ed.). The Cambridge Companion to the Greek Novel. Cambridge: Cambridge University Press, 2008, p. 218-27.

MÜLLER, Carl Werner. Cariton von Aphrodisias und die Theorie des Romans in Antike. Antike \& Abenland, v. 22, p. 115-36, 1976.

PASCHALIS, Michael. The Basic plot of Callirhoe. History, myth, and aristotelian poetics. In: PASCHALIS, Michael; PANAYOTAKIS, Stelios (Ed.). The construction of the real and the ideal in the ancient Novel. Ancient Narrative Supplementa 17. Groningen: Barkhuis \& Groningen University Library, 2013, p. 161-77.

REARDON, Bryan. P. Chariton. In: SCHMELING, Gareth (Ed.). The novel in the ancient world. Boston: Brill Academic Publishers, 2003, p. 309-35.

ROBIANO, Patrick. La citation poétique dans le roman érotique grec. Revue des Études Anciennes, v. 102, n. 3-4, p. 509-29, 2000.

SCOURFIELD, J. H. D. Anger and gender in Chariton's Chaereas and Callirhoe. In: BRAUND, Susanna; MOST, Glenn W. (Ed.). Ancient anger. Perspectives from Homer to Galen. Cambridge: Cambridge University Press, 2003, p. 163-84.

TILG, Stefan. Chariton of Aphrodisias and the invention of the Greek love novel. Oxford: Oxford University Press, 2010.

WHITMARSH, Tim. Narrative and identity in the ancient Greek novel. Cambridge: Cambridge University Press, 2011. 